\title{
Developing Virtual Braille English Audio Model for Reading Skills of Blind Students
}

\author{
Kulsum Nur Hayati \\ Balai Pengembangan Media Radio Pendidikan dan Kebudayaan Kemdikbud \\ Jalan Sorowajan Baru 367 Banguntapan Yogyakarta \\ kulsum.nur@kemdikbud.go.id
}

\begin{abstract}
:
Learning media to support blind students' English competence is still very limited. The development of Virtual Braille English Audio For Reading Skills (VB-EARS) model is aimed to produce Virtual Braille learning media model in the form of android based application to improve reading comprehension of blind students in high school. The research method consists of 2 steps: 1) pre-development step; and 2) model development step. Pre-development step are 1) to determine the tools in the form of an android-based Virtual Braille that can support blind students enhance their reading skill; 2) to determine the education level, which is Senior High School $(S M A) ; 3)$ to determine the learning presentation and interactivity format (voice response and essay answer with Virtual Braille); and 4) to determine the concept of reading material, which is narrative text. Model development step applies ADDIE model (analysis, design, development, implementation, and evaluation). The result of this model development is VB -EARS model for English subject which can improve reading comprehension skill of blind students in high school. This research has generated an overview of the application, design of the application system, navigation design, and system needs for android-based application of Virtual Braille learning audio media model to improve high school blind students' reading skill.
\end{abstract}

Keywords: audio media, Virtual Braille, blind students 


\section{INTRODUCTION}

Teaching reading competence in blind student is not as easy as teaching other students with disabilities. English Teachers in a blind school meets many difficulties, especially language skills to improve receptive skills and productive skills. Receptive skills consits of reading skills and listening skills. Productive skills consist of speaking and writing skills.

The results of interviews with English teachers in several Special Schools (SLB) in Yogyakarta indicates that there are many difficulties to learning English in aspects of language skills, especially reading comprehension. Students do not

understand the contents of the reading material and teacher has difficulty in improving students' skills.

Narrative text is a taught material to high school blind students. Narrative text is information about an event that is conveyed chronologically. Narrative text is an essay containing information about events. Narrative text has a social function to entertain readers. That makes readers happy.

Narrative text has an organizational structure using time orders. Time orders to express what happens sequentially by using words and phrases that can show time order signals. The composition of the organizational structure is a part of a narrative essay that blends into narrative essays. Barwick (2006) said that in a narrative essay, there are at least 4 parts. The parts of the narrative essay are orientation, complication, series of events, resolution, and reorientation / optional. Johns (2002) also suggests that part of a narrative essay includes an orientation (providing relevant information about the characters' situation); complication (introduces one or more problems for characters to solve); evaluation (highlights the significance of the events for characters); resolution (sorts out the problems for better or worse).

The advancement of information and communication technology (ICT) helps English language teachers guide students to learn language skills. Many tools and programs are available, such as flash. ICT can be used to create learning media. It makes English teachers and blind students understand learning material easily. The learning media for blind students is classified into: 1 ) the use of tools / objects that are real; 2) the use of assistive devices that are actually preserved; and 3) the use of objects / artificial objects (Rudiyati, 2005). It must be considered when the teacher or media developer will create a model for the blind.

The existence of ICT advances raises an idea to develop a learning media model for blind people. The choice of tools used in developing this model is a Virtual Braille keyboard based on Android. Virtual Braille keyboards are developed according to the manual Braille concept that has been understood by blind students throughout the world. Braille letters consist of cells that have 6 points arising which numbering two sequential columns down 1, 2, 3 then on the right $4,5,6$.

Writing Braille letters is like dominoes. The basic unit of this writing system is called Braille cells, where each cell consists of six points arising; three lines with two 
points. These six points can be arranged in such a way that creates 64 kinds of combinations. Braille letters are read from left to right and can symbolize the alphabet, punctuation marks, numbers, musical signs, mathematical symbols, and others. The commonly used Braille font size is $0.5 \mathrm{~mm}$ high, and horizontal and vertical spaces between points in the cell are $2.5 \mathrm{~mm}$.

The United Nations (UN) in 2006 declared an International Day for Disabled People with the theme of e-accessibility (Daksa, 2005). The meaning of this UN appeal is for the blind to have more opportunities to access information in the digital era, for example the creation of 'text-to-speeches' or 'screen reader' applications that are able to read text types on a computer screen for blind users. Currently also has designed a computer interface device with voice activation technology where the command words can control the work of computer devices.

The material in the VB-EARS Narrative Text Model is presented very interesting and interactive. VB-EARS Narrative Text is presented using a communicative approach by starting pre reading activity / exploration, while reading activity / elaboration and post reading activity / confirmation. The learning process of reading narrative text includes other reading and language skills such as integrated listening, speaking and writing.

The presentation of narrative text includes three stages. The first phase contains an introduction to the program to convey the program objectives. The second stage contains the delivery of competencies, indicators, learning objectives, and narrative text material. The third stage contains the learning of reading narrative text which includes: 1 ) pre reading activity / exploration: contains activities aimed at apperception of reading material to be discussed; 2) while reading activity I elaboration as the main activity in developing reading skills in narrative text; and 3) post reading activity / confirmation as strengthening activities involving other language skills, such as speaking and writing (Krisnawati, 2016).

The EARS model developed uses an Android application with a navigation and input / output system using the concept of Braille letters in the form of Virtual Braille Keyboard technology. Virtual Braille Keyboard is a special keyboard that is made using a 6-button system like the concept of Braille letters with Multi Touch technology, Text-to-Speech, and Speech-to-Text. The choice of using the Braille concept and collaboration with android technology because blind people have mastered Braille since childhood so they are familiar and do not need special training to use the application.

Virtual Braille for EARS (English Audio for Reading Skills) is a solution that is implemented for the education of blind people by utilizing technology and the ability of blind students themselves in the Braille field. The learning materials and exam questions are changed in audio/ sound form and can be used in the process blind learning with Virtual Braille for EARS.

The formulation research problem is how the Virtual Braille learning audio media model can be used by blind high school students to improve their reading 
comprehension skills. Based on this problem as a focus of research, audio media that contains narrative text are needed. Therefore, research is focused on the development of audio media models for learning English. This research is specifically related to improving reading ability through listening and integrated speaking and writing skills (integrated teaching) for blind students especially narrative text material.

\section{LITERATURE REVIEW}

The model created is EARS Virtual Braille based on Android. The concept of interactivity in VB EARS is inspired by 6 Braille letters that blind students have been familiar with. The aim of developing the VB-EARS model is to produce an audio learning media model in Virtual Braille, an android-based application for improving reading comprehension of blind high school students.

Blind people are not only those who are blind, but also those who are able to see but with very limited sight and cannot be used for the benefit of everyday life, especially in learning. So, people with vision conditions that include "half-sighted", "low vision", or nearsightedness are part of the blind group. Individuals with visual impairments or visually impaired are not only totally unable to see (blind) but also include those who can see but are very limited or often called low vision (Somantri, 2007: 65).

Learning services for low vision students must pay attention to: 1) the principle of enlarging writing, 2) prioritizing using objects that are real or imitation at the time of learning, 3) paying attention to information on placement of student seating, 3) using contran basic colors with writing, 5) position sit for low vision students in front, 6) pronunciation of sentences written on the board with clear sound and can use sound media such as video or sound player (Ramadani, 2017).

Blindness (visual impairment) is someone who only has the sharpness of vision $20 / 200$ or smaller in the best eye after being corrected by using glasses, or the sharpness of his vision is better than 20/200 but his vision (ability to see) narrows so that it forms an angle view is not greater than 20 degrees (Ishartiwi, 1991). Blindness means the condition of the wound or damage to the eyes or sense of sight resulting in less or no visual perception ability. This condition is caused by a real disturbance in the eye organs and / or nerves. The use of media learning and assessment of learning outcomes is adjusted to the conditions of students who are visually impaired different from those with low vision (Rahayu, Murni, \& Efrina, 2014)

Kauffman \& Hallahan (1991: 310) said that, blind people can be classified into 2 types, namely: 1 ) blind, if someone is completely unable to receive stimuli of light from the outside; and 2) low vision, if the child is still able to receive stimuli from the outside, but the sharpness is more than 6/21, or if the child is only able to read headlines in the newspaper. Smart (2010: 36) said that low vision is those who have a blurred vision when looking at an object, while a totally blind 
condition is the condition that blinds who are totally unable to see external light stimulation.

Based on that definition, blind people are classified based on two aspects, namely medical aspects based on measurements and functional aspects based on how students use their vision to master the environment.

Based on these descriptions, blind people are individuals whose sense of vision (both) does not function as a channel for receiving information in daily activities like an alert person. People with this visual impairment can be seen in condition 1) the sharpness of their vision diminishes from an alert person; 2) turbidity occurs in the eyepiece or there is a certain liquid; 3 ) eye position is difficult to control by the brain nerves; and 4) there is damage to the brain's nerve structure in the visual part. These conditions of the level of visual acuity are used as a benchmark for whether a person is blind or not. To find out the reliability of a test, a test known as the Snellen Card can be used. It should be emphasized that people are said to be blind if their visual acuity (vision) is less than 6/21.

Charles Barbier del Serre (Bertman, 2016) introduced sonography to the institution of blind children. Sonography is an artillery code used for war communication and a combination of points and lines. Barbier introduced sonography to the institution of blind children founded by Valentin Hauy in 1784. At the institution there was an intelligent and talented child, Louis Braille. He was born on January 4, 1809. He found several problems in the Barbier system, which were never used because it is very complicated.

Sonography using 12 point cells the size of a fingertip, requires time and energy to write by a needle. Sonography has no punctuation marks, numbers, tone marks, and there are many abbreviations because they represent sound rather than letters. In 1824, Louis discovered his new alphabet. He found 63 ways to use sixpoint cells. In 1860, Braille Letters was accepted as official letters in blind schools in Europe (Bertman, 2016).

Braille is a literary system for blind people. The basic unit of Braille is Braille cells. Braille letters was invented by Louis Braille, consisting of 6 points, namely the upper left point is the first point, the middle left point is the second point, the lower left point is the third point, the upper right point is the fourth point so on. Of all these points it is able to make 64 combinations. Braille letters are read from left to right. The points depicted as black are points that arise. Braille font sizes that are commonly used are $0.5 \mathrm{~mm}$ high, and horizontal and vertical spaces between 2.5 $\mathrm{mm}$ points (Sunanto, 2005: 25-26).

Indonesian uses Latin alphabet, consist of 26 letters from letters a to $z$. Thus, Braille letters also have a combination of six points as many as 26 letters, each of which represents Latin letters in Indonesian. In the picture below, you can see an alphabetical example in Braille. 


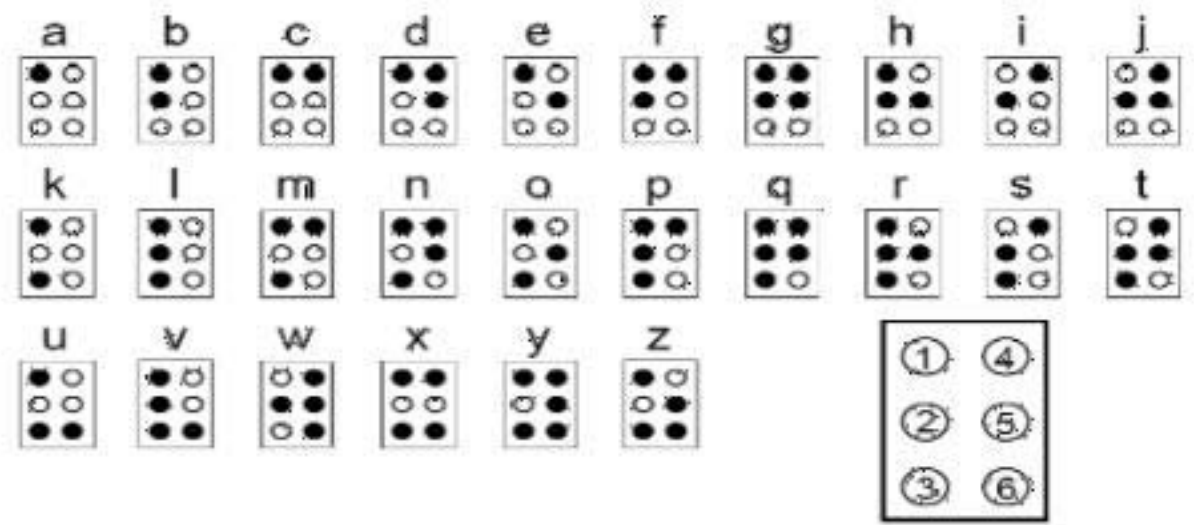

Figure 1, Alphabetical Letter of Braille

Keyboard is an important component in the computer to enter input, done by pressing the buttons. The keyboard is wired by computer. But now, there is a keyboard that has no cable, the wireless keyboard. The keyboard can be a fast input device, depending on the speed of the user in using it. The keyboard keys are generally divided into four, such as function keys, alphanumeric keys, control buttons, and numeric keys.

Android is a set of software for mobile devices that includes operating systems, middleware, and major mobile applications (Safaat, 2012). Android is a mobile operating system that adopts the Linux operating system, but has been modified. Android was taken over by Google in 2005 from Android Inc. as part of a strategy to fill the mobile operating system market. Google took over all the results of Android's work including the team that developed Android.

Google wants Android to be open and free. Therefore, almost every Android program code launched is based on the Apache open source license, which means that everyone who wants to use Android can download the full source code. In addition, hardware manufacturers can also add their own extensions to Android according to their product needs. Its simple development model makes Android attractive to hardware vendors (example: Samsung).

Android (Safaat, 2012) is available open source for hardware manufacturers to modify it as needed. Although the configuration of an Android device is not the same between devices with each other, Android itself supports features 1) Storage (storage); 2) Connectivity - supports GSM, EDGE, CDMA, EVDO, UMTS, Bluetooth (including A2DP and AVRCP), Wifi, LTE, and WiMAX; 3) Message messaging - supports SMS and MMS; 4) Dialing-supporting calls; 5) Web Browser - using open source WebKit including the Chrome V8 Java Script engine; 6) Supported media include: H.263, H.264 (3gp and MP4 container), MPEG-4 SP, AMR, AMR-WB (3GP container), AAC, HE -AAC (MP4 or 3GP container), MP3 , MIDI, Ogg Vorbis, WAV, JPEG, PNG, GIF and BMP; 7) Hardware - there is an Accelerometer Sensor, Camera, Digital Compass, Proximity Sensor and GPS; 8) 
Multi-touch-supports multi-touch screen; 9) Multi-tasking - supports multi-tasking applications; and 10) Flash-Android 2.3 support supports Flash 10.1.

\section{METHOD}

This research is development research, which is the development of audio media models for blind students. This development research includes 2 stages, namely 1) the pre-development stage; and 2) the model development stage. In the pre-development stage, the development team explored the development ideas from learning technology developers and Android-based application developers. Exploration of ideas is done through focused discussions and considering the potential that exists so as to produce a draft of the initial model design.

Data collection is done by using a focused discussion method to form an Android-based audio media model that is user friendly for blind students. The focused discussion was held on April 20-22 2017 at the Grand Mercure Hotel Yogyakarta. The population of this study is educators in blind or inclusion schools in the Special Region of Yogyakarta. The research sample consisted of 24 educators. The results of the focused discussion are analyzed descriptively by examining the general description of the application, the design of the application system, navigation design, and system requirements.

\section{RESULT AND DISCUSSION}

Audio media is one of the right media as a learning tool for blind students. According to Anderson (1987: 127), audio media is a source of teaching material that is economical, fun, and easily prepared for use by students. Once packaged, the subject matter and the order of presentation are fixed, certain, and can function

as an instructional medium for self-study. Opinions Locatis \& Atkinson (1984: 13), audio media are systems for receiving sound electronically (over wires or trough the airwaves. Audio media may be live or prerecorded and may broadcast over open or closed transmission systems. Based on some of these opinions audio media learning is one of the learning resources related to the auditory sense, which is flexible, inexpensive, practical, and can be delivered in the form of recording or broadcasting.

The development of audio media is increasingly rapid with the existence of android applications. Blind people can also take advantage of the android application facilities that are userfriendly for them. One that has been developed is Virtual Braille Keyboard. By utilizing this Virtual Braille Keyboard, blind students can access information more easily and comfortably.

Some studies show that the use of various media is effective for learning blind people. The use of Scrabbel Braille media can improve English vocabulary mastery for blind students (Indramurni, Sumekar, \& Nopitasari, 2017). The use of Puzzegi media (square quadrangle) is practical and effective to be used by blind students in 
flat-wake mathematics learning (Kurniasih, Astuti, \& Kurniawan, 2016). Flip fold media is effective in increasing neatness for blind children (Fitra, 2014). Letter card media really helps blind people know letters (Sattria, 2012). However, support from teachers and the environment also has a big influence on the development of blind students. Social support has an important role in forming self esteem, namely in fulfilling individual needs, inspiration, and motivation (Khoiroh, A. \& Paramita, P.P., 2014). The self-concept of visually impaired adolescents has internal and external dimensions, blind teenagers who have a positive self-concept about themselves, can accept their physical condition (Fitriyah \& Rahayu, 2013). Aspects of self-concept in adolescents who are visually impaired include knowledge, hope, and assessment (Fitriyah \& Rahayu, 2013). One form of social support is inclusive education. Inclusion education is an educational service where children with special needs are educated together with children with normal conditions in public education institutions (Rudiyati, 2005).

The problems faced by blind students when conducting social interactions with alert students, teachers, and principals are interactions in the learning process, learning methods that are difficult to understand, and learning media that have not matched the characteristics of students (Atmaja \& Hartono, 2016). Blind students are highly motivated in an activity when involved, can assess themselves, and plan their own actions (Azmil \& Santoso, 2013). Blind students at SLB A to access information and channel hobbies, such as reading story books (Nahlisa, Rukiyah, \& Christiani, 2015). Ketunanetraan brings due to the limitations of obtaining information so that blind children lack visual experience (Rudiyati, 2005).

\section{Application Overview}

VB-EARS in the form of an Android application is made for users who do not have the ability to see, such as blind students. VB-EARS is used to support the learning process of blind students where the subject matter and exam questions are converted into audio / sound with the support of Virtual Braille Keyboard technology. VB-EARS has a landscape display consisting of navigation buttons located on the right and left side of the screen and the main functions are in the center of the screen. The concept of Virtual Braille keyboard is inspired by the navigation applied to the ATM (Automatic Teller Machine), where the Braille Keyboard consists of 3 buttons on the left side of the screen and 3 buttons on the right side of the screen. When the button is pressed it will emit a sound representing the choice on that button and when pressed and held will carry out the action it represents.

The keyboard is controlled by using 3 fingers of the right hand and 3 fingers of the left hand, the index finger, middle finger and ring finger. Braille Keyboard has an unchanging location and formation; what changes is the function represented by the button according to the Braille Keyboard page. 


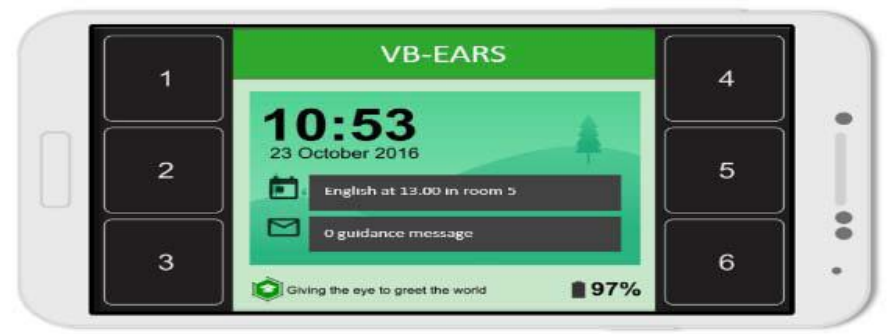

Figure 2: VB-EARS Navigation Display Concept

VB-EARS has 3 choices of input methods, namely Virtual Braille Keyboard, Speech-to -text, and OCR (Optical Character Recognition). Virtual Braille Keyboard is another function of the navigation key used for inputting letters and numbers. The way this Braille Keyboard works is to receive touch input in the form of a multi-touch combination that is translated into alphabetical letters or numbers. Another input method is speech-to-text. This method will receive input in the form of sound and change it to letters and numbers. OCR is used to read printed media such as textbooks, by directing the camera towards the picture book. Images captured by the camera will be converted into text and delivered in the form of sound.

VB-EARS has 3 output methods, namely text-to-speech, mp3 player, and visual. Text-to-Speech functions to change material texts or questions to audio I sound. Mp3 Player functions to convey material that is already in the form of sound recordings, such as listening questions in English. Then, visuals in the form of text can be adjusted in size according to the needs of the blind visionary.

\section{Design of Virtual Braille Keyboard}

VB-EARS has the advantage of the applied innovation, namely in the form of Virtual Braille Keyboard that functions, both as a navigation button and as a method of inputting letters and numbers. The concept of making a Virtual Braille Keyboard is the same as making navigation on an ATM machine, where the keys are static /

unchanged; while what changes is the function it represents according to the Keyboard's Virtual Braille page. How it works Virtual Braille Keyboard is to read a combination of finger touches. After that, the application will match the existing combination list. If there is an appropriate combination, the application will change the input into letters or numbers.

The combination used for Virtual Braille Keyboard is taken from the Braille writing system. The Braille letter consists of a series of Braille cells, where each cell consists of 6 dots. This dot combination is used to form and differentiate letters one with other letters. In Virtual Braille Keyboard, dot combinations are obtained from touch readings performed by the user and will be translated into letters and numbers. 
Touch reading is done by dividing the screen display into 2 parts horizontally and 3 parts vertically; each intersection box represents a dot in a Braille cell.



\section{Right Hand Finger \\ Left Hand Finger}

Figure 3: Screen division becomes dot Braille

The results of the touch reading will be translated and saved into the array. The array will be changed to the sum sum results as is done in converting binary numbers into decimals. The result of the conversion produces a decimal number that will be used as an index array that stores letters and numbers and is used to retrieve the characters it represents.

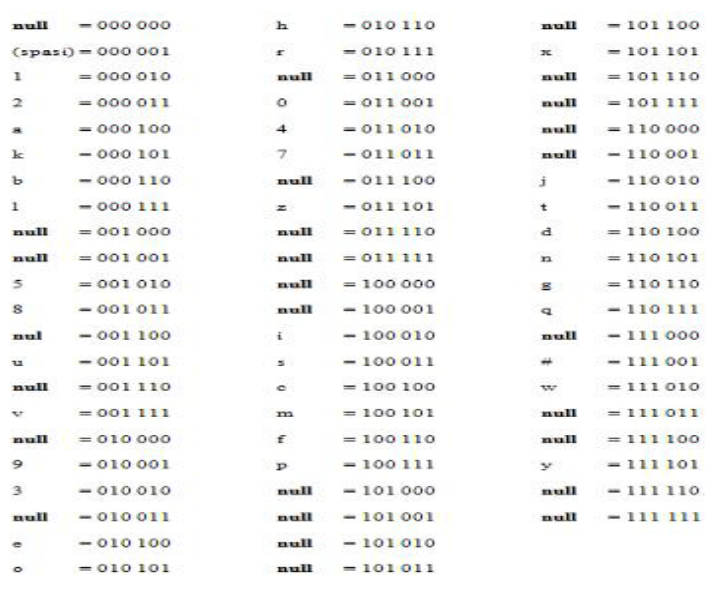

Figure 4: List of Braille Character Characters

\section{System planning}

VB-EARS consists of several functions that support the process of learning English, namely:

\section{Module Material Reader}

Serves to read material modules, both in the form of $\mathrm{mp} 3$ files that have been recorded by the developer and from text-shaped material. The material module is 
delivered in chapter or chapter format so that it can be accessed according to the desired chapter. With Text-to-Speech technology, the material is converted into audio / sound and can be controlled by reading. There is navigation to help blind users control material readings, namely:

1) Play / Pause to run and stop reading material.

2) Next Paragraph to jump to the next paragraph.

3) Previous Paragraph to jump to the previous paragraph.

4) Next Chapter to move to the next chapter.

5) Previous Chapter to move to the previous chapter.

The module reader can also be used to read printed books, by directing the camera to a prepared book equipped with QR-CODE, and then it will be translated into sound.

\section{Multiple Choice Exams and Essays}

Works to do multiple choice tests where the center of the application displays a question and issues instructions or questions by pressing once, and the navigation section ( 6 buttons on the right and left) functions to choose multiple choice answers. There are also shortcuts to move to other questions quickly so users can work on the questions randomly / not necessarily sequentially.

For essay exams, the middle part of the application displays a question and issues an instruction or question by pressing once, and then there is the option to input the answer / edit the answer. Answers can be written, either with Virtual Braille Keyboard or with Speech-to-Text where the user only needs to say the answer, and the user's voice will be changed to text.

\section{Academic Schedule}

To find out the academic schedule, such as class schedules or exam schedules, blind users can find out more accurately the lesson / exam time. There is a notification when the time is approaching the start of the lesson / exam.

\section{Settings}

The settings of the VB-EARS application can be adjusted to the user's needs, which consists of pronunciation speed and button size. Speech speed serves to adjust the pronunciation speed of text-to -speech according to the user's ability to listen to sound. The button size, button height and width, can be reset according to the size of the user's finger so that the VB-EARS application can be used by users, both small and large (can reach many ages).

\section{Tutorial}

Serves to train new users to recognize and understand the functions and working concepts of VB-EARS navigation. 


\section{Navigation Design}

VB-EARS has simple and easy-to-use navigation because there is a voice over on each button that shows the function of each button. Figure 5 below presents the design of VB-EARS navigation.



Figure 5. VB-EARS navigation

\section{System Requirements}

To run VB-EARS an Android smartphone with the following specifications is needed

Table 1 Smartphone Specification

\begin{tabular}{|l|l|}
\hline Component & Specification \\
\hline Screen Size & $>4$ inch \\
\hline RAM & 1 GB \\
\hline Multi-Touch & 5 multitouch \\
\hline Koneksi & $3 \mathrm{G} / 4 \mathrm{G} /$ Wifi \\
\hline Prossesor & $\begin{array}{l}\text { Mediatek MT 6582, } \\
\text { Cortex A7 } 1.3 \mathrm{GHz} \\
\text { (or more than it) }\end{array}$ \\
\hline $\begin{array}{l}\text { Memori } \\
\text { Internal }\end{array}$ & $8 \mathrm{~GB}$ \\
\hline Kamera & $5 \mathrm{MP}$ \\
\hline $\begin{array}{l}\text { Android } \\
\text { Version }\end{array}$ & $>$ Android 4.0 \\
\hline
\end{tabular}

\section{CONCLUSION AND SUGGESTION}

The results of the study and discussion show a general description of the application, application system design, navigation design, and system requirements. This research has produced a draft design for the development of learning audio media models in the Virtual Braille format in the form of Android-based applications. The model, Virtual Braille English Audio For Reading Skills (VB-EARS) is useful for 
increasing the ability of blind blind high school students to read comprehension (reading comprehension).

Regarding the implementation of the Virtual Braille model for English Audio for Reading Skills (VB -EARS), which needs to be considered in further development is the user's ability to operate the application model and the user's purchasing power to get a smartphone with the appropriate specifications.

\section{REFERENCES}

\section{Books}

Anderson, Ronald H. 1987. Pemilihan dan pengembangan media untuk pembelajaran. Diterjemahkan oleh Yusufhadi Miarso. Jakarta: Rajawali Pers. http://daksa.or.id (Diakses tanggal 03 Desember 2005).

Hallahan, D. P., Kauffman, J M. 1991. Exceptional Children: Introduction to Special Education. Fifth Edition. Virginia: New Prentice Hall International Inc.

Krisnawati, E. 2016. Buku Bahasa Inggris untuk Tunanetra. Jakarta: Direktorat Pembinaan PKLK.

Locatis, Craig N. \& Atkinson, Francis D. 1984. Media and technology for education and training. Ohio: Bell \& Howell Company Colombus.

Safaat, Nazaruddin. 2012. Pemrograman Aplikasi Mobile Smartphone dan Tablet PC Berbasis Android. Bandung: Informatika.

Smart, Aqila. 2010. Anak Cacat Bukan Kiamat: Metode Pembelajaran untuk Anak Berkebutuhan Khusus. Yogyakarta: Ar-Ruzz Media.

Somantri, Sutjihati. 2007. Psikologi Anak Luar Biasa. Bandung: PT Refika Aditama.

Sunanto, Juang. 2005. Mengembangkan Potensi Anak Berkelainan Penglihatan. Jakarta: Departemen Pendidikan Nasional.

\section{Journals/ Proceedings/ Dissertations/ Theses}

Atmaja, A.D. \& Hartono, W. 2016. Interaksi Sosial Siswa Tunanetra dalam Belajar, Surabaya: Jurnal Pendidikan Khusus, September 2016, Vol.3, No.3, hal. 50-62.

Azmil, S.N. \& Santoso, A. 2013. Bimbingan Konseling Islam dengan Media Braille dalam Meningkatkan Motivasi Diri pada Penyandang Tuna Netra, Surabaya: Jurnal Bimbingan Konseling Islam Fakultas Dakwah. Februari 2013, Vol.03, No. 02, hal. 140-151. 
Bertman, S. 2016. History Today. Retrieved from History Today: https://www.history today.com/stephen-bertman/louis-Braille-and-night-writer (Diakses pada tanggal 14 Juli 2016).

Fitra, A. 2014. Efektivitas Media Flip Fold dalam Meningkatkan Kerapian Melipat pakaian bagi Tunanetra di SLB A Payakumbuh, Padang: Jurnal Pendidikan IImiah Pendidikan Khusus, April 2014, Vol.3, No.2, hal. 106-117.

Fitriyah, C. \& Rahayu, S.A. 2013. Konsep Diri pada Remaja Tunanetra di yayasan Pendidikan Anak Buta (YPAB) Surabaya. Surabaya: Jurnal Penelitian Psikologi, April 2013, Vol. 04, No. 01, hal. 46-60.

Indramurni, Sumekar, G., \& Nopitasari, M.. 2017. Model Pembelajaran bahasa Inggris Anak Tunanetra berbasis Permainan Scrabbel Braille. Padang: Jurnal Pendidikan Kebutuhan Khusus, Februari 2017, Vol.1, No.1, hal. 1-8.

Ishartiwi. 1991. Keefektifan Penggunaan Media Audio (Talking Book) dalam Kegiatan Belajar Tunanetra. Tesis. Malang: Fakultas Pascasarjana-IKIP Malang.

Johns, Ann M. 2002. Genre in the Classroom: Multiple Perspective. New Jersey: Lawrence Erlbaum Associates, Inc.

Khoiroh, A. \& Pramesti, P.P.2014. Peran Dukungan Sosial terhadap pembentukan Self Esteem yang Tinggi pada Remaja Tunanetra di Sekolah Khusus, Surabaya: Jurnal Psikologi Industri dan Organisasi, Desember 2014, Vol. 3, No. 3, hal. 129136.

Kurniasih, N., Astuti, E.P., Kurniawan, H. 2016. Pengembangan Puzzegi (Puzzle Segiempat) sebagai Media Pembelajaran Matematika pada Siswa Tunanetra. Surakarta: Prosiding Seminar Matematika dan Pendidikan Matematika, November 2016, hal. 57-66

Nahlisa, R.M., Rukiyah, \& Christiani, L. 2015. Buku Braille sebagai Jembatan Keterbatasan Akses Informasi Siswa Tunanetra Sekolah Luar Biasa Bagian A Dra Adi Semarang. Semarang: Jurnal Ilmu Perpustakaan, April 2015, Vol. 4, No. 2, hal. 1-8.

Rahayu, R., Murni, I., \& Efrina, E., Penyelenggaraan Pendidikan Inklusif bagi Anak Tunanetra Low Vision, Padang: Jurnal Imliah Pendidikan Khusus, September 2014, Vol.3, No.3, hal. 502-515.

Ramadani, I.D. 2017. Layanan Pendidikan Bagi Siswa Tunanetra Low Vision Kelas V SD Muhammadiyah Bogor, Bogor: Jurnal Pendidikan Guru Sekolah Dasar, Edisi 9 Tahun ke-6, hal: 858-865. 
Rudiyati, S. 2005. Pengembangan Materi dan Alat Bantu Pembelajaran Anak Tunanetra di Sekolah Terpadu/Inklusi, Yogyakarta: Jurnal Pendidikan Khusus, November 2005, Vol. 1, No. 2, hal. 88-103.

Sattria, R. 2012. Meningkatkan Kemampuan Mengenal Huruf Braille melalui Media Kartu Huruf Anak Tunanetra, Padang: Jurnal Imliah Pendidikan Khusus, September 2012, Vol.1, No.3, hal. 332-343.

\section{ABOUT THE AUTHORS}

Kulsum Nur Hayati: Fungsional Pengembang Teknologi Pembelajaran, Perancangan Model, Balai Pengembangan Media Radio Pendidikan dan Kebudayaan (BPMRPK) Kemendikbud, Yogyakarta, Indonesia. 